\title{
ANALISIS KELAYAKAN SOSIAL DAN FINANSIAL PEMBUATAN TAMBAK UDANG DI KABUPATEN MUKOMUKO PROPINSI BENGKULU
}

\author{
Sri Wahyuni
}

\begin{abstract}
This research was conducted in Dusun Baru Pelokan Kecamatan Mumomuko Utara Kabupaten Mukomuko from July to September 2007 and aimed analysis feasibility the project of social and financial aspect. The research location was selected purposively. The population in this research was the society of Dusun Baru Pelokan are $415 \mathrm{KK}$, the sample taken by the Proportional Random Sampling Method. The qualitative analysis used of scor to see perception and people knowledge of Shrimp Culture. The quantitative analysis to show number use investment criteria analysis Gross B/C ratio, Net B/C ratio, Net Present Value, Profitability ratio, Internal Rate of Return (IRR), Payback Periode and Sensitivity Analysis.
\end{abstract}

Key Words : Shrimp Culture, The Feasibility Social and Financial

\section{PENDAHULUAN}

Sedikitnya terdapat sepuluh subsektor ekonomi kelautan yang memiliki prospek bisnis cerah untuk dikembangkan, memajukan dan memakmurkan Indonesia. Kesepuluh itu adalah (1) perikanan tangkap, (2) perikanan budidaya, (3) industri pengolahan hasil perikanan, (4) industri bioteknologi, (5) pertambangan dan energi, (6) pariwisata bahari, (7) transportasi laut, (8) industri dan jasa maritim, (9) pembangunan pulau-pulau kecil dan (10) sumber daya non konvensional (non-conventional resource).(Dahuri, 2005)

Potensi besar ditunjukkan oleh perikanan budidaya. Meski belum optimal karena tingginya investasi yang harus ditanamkan, perikanan budidaya memiliki potensi yang terbilang cukup besar. Secara total, perikanan budidaya memiliki potensi 60 juta ton per tahun yang terdiri atas perikanan budidaya di laut, tambak dan perairan air tawar.

Udang merupakan salah satu komoditi dari jenis perikanan budidaya. Hingga akhir 2004, Indonesia memiliki potensi lahan tambak udang seluas 913.000 ha. Lahan tersebut belum sepenuhnya dimanfaatkan secara optimal. Dari segi volume ekspor, komoditas 
udang tahun 1995 mencapai 94,511 ton dengan nilai ekspor mencapai 1.037 juta US \$. Nilai dan volume yang besar tersebut menjadikan udang sebagai komoditas dengan kontribusi sebesar $35 \%$ dari total ekspor produk pertanian Indonesia. (BEINEWS, 2005)

Wilayah perairan pantai Kabupaten Mukomuko termasuk dalam klasifikasi perairan Pantai Barat Sumatera dan mempunyai garis pantai yang bersinggungan dengan Samudera Hindia. Sebagian besar penduduk Kabupaten Mukomuko bekerja pada subsektor perikanan laut. Tangkapan di laut memang masih bisa dikembangkan, tetapi memerlukan biaya yang lebih mahal sehingga dapat menghambat produksi. Peningkatan produksi yang mungkin dapat dilakukan adalah pada subsektor perikanan budidaya, salah satunya adalah budidaya tambak udang intensif.

Kajian aspek sosial dalam penelitian ini dirasakan sangat penting karena menggambarkan kesiapan calon petani plasma di daerah penelitian. Kesiapan calon petani plasma mencakup persepsi masyarakat dan tingkat pengetahuan masyarakat terhadap usulan pembuatan tambak udang di Kabupaten Mukomuko. Analisis finansial ini dirasakan perlu untuk membuat proyeksi mengenai anggaran yang akan mengestimasi penerimaan dan pengeluaran bruto pada masa-masa yang akan datang setiap tahun. Oleh karena itu, peneliti tertarik untuk meneliti keadaan ini dengan cara menganalisis kelayakan aspek sosial dan finansial tambak udang di Kabupaten Mukomuko

\section{METODOLOGI PENELITIAN}

Penelitian ini dilaksanakan di Desa Dusun Baru Pelokan Kecamatan Mukomuko Utara Kabupaten Mukomuko. Lokasi penelitian dilakukan secara sengaja (purposive) dengan pertimbangan bahwa di Desa tersebut memiliki lahan yang cukup luas, dengan sumber air yang mendukung potensi daerah ini untuk dijadikan tambak udang karena calon lokasi tambak lokasi tambak berdekatan dengan air laut, dan muara Sungai Manjunto dan 
Sungai Semeluk. Sedangkan data finansial, diambil pada perusahaan Tambak Udang Kilau Samudera Pondok Kelapa Bengkulu Utara.

Populasi dalam penelitian ini adalah masyarakat di Desa Dusun Baru Pelokan Kecamatan Mukomuko Utara Kabupaten Mukomuko dengan jumlah KK 415 orang. Penentuan sampel pada masing-masing bagian di daerah penelitian dilakukan secara Proporsional Random Sampling. Untuk memperoleh Bound Of Error (dilakukan cobacoba, ditentukan jumlah sampel awal dari 10 persen populasi yaitu 42 responden karena telah mewakili populasi, sehingga (Bound of error $=0,14$ ), $\mathrm{D}=0,0049, \mathrm{~N}=415$ dan $\mathrm{p}=$ 0,5, maka didapat jumlah responden menurut proporsinya yaitu petani 45 responden, wiraswasta 8 orang dan PNS 7 orang.

Analisis aspek sosial dalam penelitian ini digunakan untuk mengetahui persepsi dan tingkat pengetahuan masyarakat di daerah penelitian agar dapat menjelaskan sejauh mana kesiapan calon petani plasma terhadap usulan tambak udang. Analisis sosial ini dapat memberikan estimasi-estimasi sosial terhadap tambak udang yang akan dibangun.

Jawaban dari setiap pernyataan persepsi :

$$
\begin{array}{ll}
5 & =\text { Sangat Setuju } \\
3 & =\text { Ragu-ragu } \\
1 & =\text { Tidak Setuju }
\end{array}
$$

Adapun jawaban yang disediakan untuk mengetahui pengetahuan masyarakat terhadap budidaya tambak udang:

$$
\begin{aligned}
5 & =\text { Tahu } \\
3 & =\text { Kurang tahu } \\
1 & =\text { Tidak Tahu }
\end{aligned}
$$

Sementara, kriteria bagi responden yang mempunyai persepsi baik adalah jika responden tersebut memperoleh nilai skor > nilai tengah, dan responden yang mempunyai persepsi kurang baik adalah jika responden tersebut memperoleh nilai skor $\leq$ nilai tengah. Nilai tengah $=$ Nilai bawah $+\{($ Nilai atas - Nilai bawah $): 2\}=10+\{(50-10): 2\}=30$ 
1. $\boldsymbol{N P V}=\frac{}{(1+\mathrm{i}) \mathrm{t}}$ atau

$$
\text { NPV }=P V \text { Benefit }-P V \text { Cost }
$$

Kriteria NPV >0, usaha layak untuk dilaksanakan

NPV $<0$, usaha tidak layak untuk dilaksanakan

(Gray,dkk.1993)

2. Gross $B / C$ ratio $=\sum_{t=0}^{n}-B t$

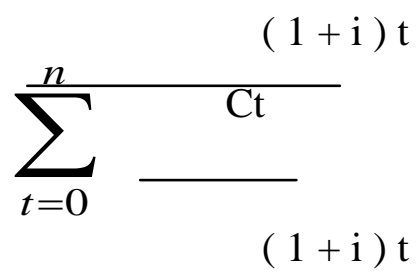

Kriteria Gross B/C > 1, usaha layak untuk dilaksanakan

$\mathrm{B} / \mathrm{C}<1$, usaha tidak layak untuk dilaksanakan

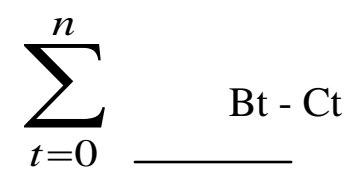

3. Net $B / C$ ratio $=\sum_{t=0}^{n} \frac{(1+\mathrm{i})^{\mathrm{t}}}{\mathrm{Ct}-\mathrm{Bt}}$

$$
(1+\mathrm{i})^{\mathrm{t}}
$$

Kriteria Net B/C > 1, usaha layak untuk dilaksanakan

Net $\quad B / C<1$, usaha tidak layak untuk dilaksanakan

$$
\text { 4. } \boldsymbol{I R} \boldsymbol{R}=\mathrm{i}_{1}+\frac{\mathrm{NPV} \mathrm{V}_{1}}{\mathrm{NPV}_{1}-\mathrm{NPV}_{2}} \quad\left(\mathrm{i}_{2}-\mathrm{i}_{1}\right)
$$

Keterangan :

- Net B/C : Rasio penerimaan bersih

- NPV : Nilai bersih sekarang dari keuntungan

- IRR : Tingkat bunga yang dicari 
- $\mathrm{NPV}_{1}$ : Nilai sekarang pada $\mathrm{I}_{1}$

- $\mathrm{NPV}_{2}:$ Nilai sekarang pada $\mathrm{I}_{2}$

- Bt : Manfaat pada tahun $\mathrm{t}$

- $\mathrm{Ct} \quad$ : Biaya pada tahun $\mathrm{t}$

- O \& M : Biaya Operasioanal dan maintenance (biaya rutin) tahun ke t

- $\mathrm{t} \quad$ : Umur ekonomis investasi (tahun proyek)

- it $\quad$ : Biaya investasi pada tahun ke $\mathrm{t}$

- $\mathrm{i}_{1} \quad$ : Tingkat suku bunga pertama

- $\mathrm{i}_{2} \quad$ : Tingkat suku bunga kedua

- n : jumlah tahun

6. Payback Period (PP)

$$
\mathrm{PP}=\frac{\text { Total Investasi }}{\text { Penghasilan per tahun }}
$$

\section{Analisis Sensitivitas}

Analisis sensitivitas bertujuan untuk melihat apa yang terjadi dengan hasil analisa proyek jika ada suatu perubahan dalam perhitungan biaya dan penerimaan. Hal ini dilakukan karena analisis investasi tambak udang didasarkan pada perkiraan yang banyak mengandung ketidakpastian tentang apa yang terjadi pada masa yang akan datang. Analisis ini dilakukan dengan cara coba-coba (try dan error).

\section{HASIL DAN PEMBAHASAN}

\section{Kelayakan Dari Aspek Sosial}

Tabel 1.Tingkat Persepsi Masyarakat Terhadap Rencana Pembuatan Tambak Udang di Desa Dusun Baru Pelokan Kabupaten Mukomuko.

\begin{tabular}{lc}
\hline \multicolumn{1}{c}{ Tingkat Persepsi } & Persentase $(\%)$ \\
\hline Baik ( > nilai tengah) & 95 \\
Kurang Baik ( $\leq$ nilai tengah) & 5 \\
\hline & 100,00 \\
\hline
\end{tabular}

Sumber : Data Primer Diolah,2007 
Selanjutnya, berdasarkan kriteria pengambilan keputusan dengan menggunakan 2 kategori seperti di atas dapat dikatakan bahwa masyarakat di Desa Dusun Baru Pelokan mempunyai tingkat persepsi yang baik terhadap inovasi baru yaitu rencana pembuatan tambak udang, hal ini dapat diketahui dari jumlah persentase dari masyarakat yang memiliki skor > nilai tengah mencapai $95 \%$.

Tabel . Bentuk Pernyataan dalam Menilai Persepsi Masyarakat Terhadap Usulan PembuatanTambak Udang Di Desa Dusun Baru Pelokan (N=60)

\begin{tabular}{|c|c|c|c|c|}
\hline \multirow[b]{2}{*}{ No } & \multirow[b]{2}{*}{ Pernyataan-pernyataan } & \multicolumn{3}{|c|}{ Persentase $(\%)$} \\
\hline & & $\begin{array}{l}\text { Sangat } \\
\text { Setuju }\end{array}$ & $\begin{array}{l}\text { Kurang } \\
\text { Setuju }\end{array}$ & $\begin{array}{l}\text { Tidak } \\
\text { Setuju }\end{array}$ \\
\hline 1 & $\begin{array}{l}\text { Tambak udang akan meningkatkan peluang kerja } \\
\text { bagi anggota keluarga }\end{array}$ & 85 & 13,3 & 1,67 \\
\hline 2 & $\begin{array}{l}\text { Dengan tambak udang akan meningkatkan } \\
\text { pendapatan masyarakat sehingga ekonominya lebih } \\
\text { baik atau stabil }\end{array}$ & 66,7 & 28,3 & 5 \\
\hline 3 & $\begin{array}{l}\text { Tambak udang yang dibangun dapat memajukan } \\
\text { Desa. }\end{array}$ & 88,3 & 6,67 & 5 \\
\hline 4 & $\begin{array}{l}\text { Tambak udang merupakan alternatif pengembangan } \\
\text { perikanan darat di Kabupaten Mukomuko }\end{array}$ & 88,3 & 10 & 1,67 \\
\hline 5 & $\begin{array}{l}\text { Tambak udang merupakan program Pemerintah } \\
\text { Kabupaten Mukomuko yang harus kita dukung. }\end{array}$ & 88,3 & 10 & 1,67 \\
\hline 6 & $\begin{array}{l}\text { Lahan di Desa Dusun Baru Pelokan mendukung } \\
\text { untuk dijadikan tambak }\end{array}$ & 28,3 & 70 & 1,67 \\
\hline 7 & $\begin{array}{l}\text { Tambak udang dapat mengurangi pengangguran di } \\
\text { Desa dan dapat mengurangi migrasi ke kota. }\end{array}$ & 91,7 & 8,33 & 0 \\
\hline 8 & $\begin{array}{l}\text { Usaha tambak dapat dijadikan sebagai pekerjaan } \\
\text { pokok atau pekerjaan sampingan masyarakat Desa }\end{array}$ & 83,3 & 10 & 1,67 \\
\hline 9 & $\begin{array}{l}\text { Usaha tambak udang lebih disukai petambak karena } \\
\text { dalam hal pemasaran udang lebih menguntungkan }\end{array}$ & 85 & 15 & 0 \\
\hline 10 & $\begin{array}{l}\text { Usaha tambak memerlukan modal yang cukup } \\
\text { besar. }\end{array}$ & 96,7 & 3,33 & 0 \\
\hline
\end{tabular}

Sumber : Data Primer Diolah, Tahun 2007

Tabel 2. Tingkat Pengetahuan Masyarakat Terhadap Budidaya Tambak Udang

\begin{tabular}{lc}
\hline \multicolumn{1}{c}{ Tingkat Pengetahuan } & Persentase $(\%)$ \\
\hline Tinggi ( > nilai tengah ) & 85 \\
Rendah ( $\leq$ nilai tengah ) & 15 \\
\hline & 100,00 \\
\hline
\end{tabular}

Sumber : Data Primer Diolah, 2007

Selanjutnya, berdasarkan kriteria pengambilan keputusan dengan menggunakan 2 kategori seperti di atas dapat dikatakan bahwa masyarakat di Desa Dusun Baru Pelokan 
mempunyai tingkat pengetahuan yang tinggi terhadap budidaya tambak udang, hal ini dapat diketahui dari jumlah persentase dari masyarakat yang memiliki skor > nilai tengah sebesar $85 \%$.

Tabel. Bentuk Pernyataan Untuk Menilai Tingkat Pengetahuan Masyarakat Terhadap Budidaya Tambak Udang $(\mathrm{N}=60)$

\begin{tabular}{|c|c|c|c|c|}
\hline \multirow[b]{2}{*}{ No } & \multirow[b]{2}{*}{ Pernyataan-pernyataan } & \multicolumn{3}{|c|}{ Persentase $(\%)$} \\
\hline & & Tahu & $\begin{array}{c}\text { Kuran } \\
\text { g } \\
\text { Tahu }\end{array}$ & $\begin{array}{l}\text { Tidak } \\
\text { Tahu }\end{array}$ \\
\hline 1. & $\begin{array}{l}\text { Tambak merupakan empang/pematang/petakan yang } \\
\text { berisi air dekat pantai laut. }\end{array}$ & 83,3 & 8,3 & 8,3 \\
\hline 2. & $\begin{array}{l}\text { Budidaya udang di tambak adalah kegiatan usaha } \\
\text { pemeliharaan udang/pembesaran udang mulai dari } \\
\text { ukuran benih }(0,15-70 \mathrm{~mm}) \text { sampai menjadi ukuran } \\
\text { yang layak untuk dikonsumsi. }\end{array}$ & 48,3 & 43,3 & 8,3 \\
\hline 3. & $\begin{array}{l}\text { Pada lokasi tambak udang harus tersedia sumber air laut } \\
\text { dan air payau sebagai sumber pengairan tambak. }\end{array}$ & 80 & 13,3 & 6,7 \\
\hline 4. & $\begin{array}{l}\text { Lokasi tambak udang adalah daerah dengan perbedaan } \\
\text { pasang surut cukup tinggi. }\end{array}$ & 20 & 56,7 & 23,3 \\
\hline 5. & $\begin{array}{l}\text { Hutan bakau selebar } 15 \mathrm{~m} \text { dapat melindungi tambak } \\
\text { dari gangguan ombak. }\end{array}$ & 25 & 51,7 & 23,3 \\
\hline 6. & Jarak lokasi tambak dari pantai maksimal $1 \mathrm{~km}$. & 45 & 45 & 10 \\
\hline 7. & $\begin{array}{l}\text { Kadar garam tambak yang terlalu tinggi terjadi pada } \\
\text { musim kemarau yang membuat pertumbuhan udang } \\
\text { lebih cepat namun sensitif terhadap penyakit }\end{array}$ & 13,3 & 38,3 & 48,3 \\
\hline 8. & $\begin{array}{l}\text { Pematang tambak harus cukup tinggi untuk mencegah } \\
\text { peluapan air pada saat banjir atau pasang tertinggi }\end{array}$ & 76,7 & 15 & 8,3 \\
\hline 9. & $\begin{array}{l}\text { Pematang tambak harus cukup lebar untuk } \\
\text { memudahkan kegiatan. }\end{array}$ & 78 & 17 & 6,7 \\
\hline 10. & $\begin{array}{l}\text { Tambak harus mempunyai pintu pemasukan dan } \\
\text { pengeluaran air yang cukup baik. }\end{array}$ & 78,3 & 15 & 6,67 \\
\hline 11. & $\begin{array}{l}\text { Benih udang dapat diperoleh secara alami dan melalui } \\
\text { hasil pembibitan yang sengaja dilakukan. }\end{array}$ & 32 & 60 & 8 \\
\hline 12. & $\begin{array}{l}\text { Benih udang alami bisa diperoleh dari pantai, saluran } \\
\text { air dan sungai kecil. }\end{array}$ & 40 & 48,3 & 11,7 \\
\hline 13. & $\begin{array}{l}\text { Benih udang hasil pembibitan diperoleh dengan cara } \\
\text { menangkap induk betina yang telah matang di laut. }\end{array}$ & 18,3 & 70 & 11,7 \\
\hline 14. & Makanan alami udang pada tambak berupa plankton & 38 & 50 & 12 \\
\hline 15. & Pemberantasan hama perlu dilakukan pada tambak. & 68,3 & 23,3 & 8,3 \\
\hline 16. & $\begin{array}{l}\text { Hama yang sering merugikan adalah ikan buas, } \\
\text { kepiting, ular air, ular kadut, burung bangau, anjing air } \\
\text { dan siput. }\end{array}$ & 55 & 35 & 10 \\
\hline 17. & Pemberian pupuk urea, TSP dan saponin (obat-obatan) & 65 & 23,3 & 12 \\
\hline
\end{tabular}


diperlukan dalam pemeliharaan /pengolahan tambak.

18. Penebaran benih harus dilakukan secara merata di seluruh permukaan tambak agar tidak memadat di suatu tempat.

$68,3 \quad 23,3 \quad 8,3$

19. Padatnya benih di suatu tempat dapat menimbulkan persaingan benih udang untuk mendapatkan makanan sehingga dapat merugikan usaha pemeliharaan.

20. Penebaran benih dilakukan sore atau pagi hari karena pada keadaan tersebut suhu air relatif rendah.

21. Lama pemeliharaan udang 4-5 bulan

enan

22. Pemanenan sekaligus dapat dilakukan dengan cara mengeringkan petakan tambak.

$\begin{array}{lll}47 & 45 \quad 8\end{array}$

$\begin{array}{lll}32 & 37 & 15\end{array}$

$\begin{array}{lll}37 & 53 \quad 10\end{array}$

23. Hasil/produksi suatu tambak adalah ikan bandeng dan udang

24. Udang mempunyai kandungan protein yang lebih tinggi dari ikan.

$\begin{array}{lll}72 & 17 & 12\end{array}$

$58,3 \quad 35 \quad 6,7$

25. Jenis udang yang dipelihara di tambak adalah udang Windu dan udang putih.

$52 \quad 35 \quad 13$

26. Pengolahan tambak secara intensif memerlukan biaya yang lebih besar dibandingkan dengan pegolahan tambak secara ekstensif (tradisional).

Sumber : Data Primer Diolah, 2007 (Lampiran 8)

\section{Biaya Variabel Usaha Tambak Udang.}

Tabel 3. Biaya Operasional dan Pemeliharaan Usaha Tambak Udang $450 \mathrm{Ha}$ Di Kabupaten Mukomuko Tahun 2007.

\begin{tabular}{|c|c|c|c|c|}
\hline \multirow{2}{*}{ No } & \multirow{2}{*}{ Jenis Biaya } & \multicolumn{2}{|c|}{ Biaya $(\mathrm{Rp})$} & \multirow{2}{*}{ Persen $(\%)$} \\
\hline & & $450 \mathrm{Ha} /$ siklus & $450 \mathrm{Ha} /$ tahun & \\
\hline & Biaya Variabel & & & \\
\hline 1. & Persiapan & 900.000 .000 & 1.800 .000 .000 & 0,8073 \\
\hline 2. & Benur Venname & 14.400 .000 .000 & 28.800 .000 .000 & 12,9174 \\
\hline \multirow[t]{6}{*}{3.} & Saprotan & & & \\
\hline & - Urea & 72.000 .000 & 144.000 .000 & 0,0645 \\
\hline & - SP-36 & 45.000 .000 & 90.000 .000 & 0,0403 \\
\hline & - Saponin & 630.000 .000 & 1.260 .000 .000 & 0,5651 \\
\hline & - Ziolit & 1.080 .000 .000 & 2.160 .000 .000 & 0,9688 \\
\hline & - Kapur & 1.800 .000 .000 & 3.600 .000 .000 & 1,6148 \\
\hline \multirow[t]{5}{*}{4.} & Pakan & & & \\
\hline & - Tepung & 9.900 .000 .000 & 19.800 .000 .000 & 8,8807 \\
\hline & - Crumble & 19.800 .000 .000 & 39.600 .000 .000 & 17,7615 \\
\hline & - Pellet 1. & 19.800 .000 .000 & 39.600 .000 .000 & 17,7615 \\
\hline & - Pellet 2. & 29.700.000.000 & 59.400 .000 .000 & 26,642 \\
\hline 5. & Pemeliharaan dan Perawatan & 150.000 .000 & 300.000 .000 & 0,1345 \\
\hline 6. & Telepon & 30.000 .000 & 60.000 .000 & 0,0269 \\
\hline 7. & Listrik & 8.640 .000 .000 & 17.280 .000 .000 & 7,7505 \\
\hline 8. & Tenaga kerja & 4.500.000.000 & 9.000 .000 .000 & 4,0367 \\
\hline 9. & Administrasi & 30.000 .000 & 60.000 .000 & 0,0269 \\
\hline
\end{tabular}


\begin{tabular}{rrrr}
\hline Biaya Variabel & 111.477 .000 .000 & 222.954 .000 .000 & 100,00 \\
\hline
\end{tabular}

Sumber : Data Primer Diolah, tahun 2007

Pengeluaran biaya variabel tertinggi terletak pada pembelian pakan. Biaya paling besar yang dikeluarkan setiap tahunnya adalah biaya penggunaan pakan jenis pellet 2 yaitu sebesar Rp 59.400.000.000 atau sebesar 26,642 \%, diikuti dengan pakan jenis pellet 1 sebesar 17,76\% dan crumble sebesar 17,76 \% atau senilai Rp.39.600.000.000.. Hal ini sesuai dengan hasil penelitian Koeshendrajana (2001), pada budidaya udang galah di Kabupaten Gianyar Bali, pengelolaan lahan skala besar $( \pm 200 \mathrm{Ha})$ pengeluaran biaya tertinggi terletak pada pembelian pakan. Hal ini karena pada pengelolaan lahan skala besar, benur yang ditebar relatif lebih banyak sehingga biaya untuk pengeluaran pakan menjadi besar.

Tabel 4. Biaya Tetap Usaha tambak Udang Di Kabupaten Mukomuko

\begin{tabular}{|c|c|c|c|}
\hline & Uraian Biaya Tetap & Biaya/tahun (Rp) & Proporsi (\%) \\
\hline & Biaya Tetap & & \\
\hline \multirow[t]{6}{*}{1} & Tenaga Kerja Tak Langsung & & \\
\hline & Teknisi Kepala & 36.000 .000 & 0,1572 \\
\hline & Teknisi & 1.080 .000 .000 & 4,7164 \\
\hline & Operator & 4.050 .000 .000 & 17,686 \\
\hline & Staf Adm Keuangan & 24.000 .000 & 0,1048 \\
\hline & Satpam & 216.000 .000 & 0,9433 \\
\hline 2 & Listrik & 30.000 .000 & 0,1310 \\
\hline 3 & Pemeliharaan dan Perawatan & 50.000 .000 & 0,2183 \\
\hline 4 & Penyusutan Aktiva Tetap & 15.409 .170 .455 & 67,2927 \\
\hline 5 & Pajak PBB. 1,5\% & 308.460 .000 & 1,3470 \\
\hline 6 & Asuransi $2 \%$ & 1.695.077.500 & 7,4025 \\
\hline & Biaya Tetap & 22.898 .707 .955 & 100,00 \\
\hline
\end{tabular}

Sumber : Data Primer Diolah,Tahun 2007

\section{Biaya investasi Usaha Tambak Udang 500 Ha}

Biaya investasi tambak udang terdiri dari : Biaya Pra Proyek, Resevoir, Konstruksi Tambak, Peralatan Pendukung Tambak, Prasarana Perumahan, Peralatan Kantor dan Peralatan Transportasi.

Tabel 5. Biaya Investasi Tambak Udang 500 Ha Di Kabupaten Mukomuko 


\begin{tabular}{lcc}
\hline \multicolumn{1}{c}{ Uraian } & Biaya (Rp) & $\begin{array}{c}\text { Persentase } \\
(\%)\end{array}$ \\
\hline Biaya Pra Proyek & 20.915 .000 .000 & 7,956 \\
Resevoir & 45.000 .000 .000 & 17,119 \\
Konstruksi Tambak & 119.387 .500 .000 & 45,1492 \\
Peralatan Pendukung Tambak & 71.517 .875 .000 & 27,2079 \\
Prasarana Perumahan & 5.680 .000 .000 & 2,1608 \\
Peralatan Kantor & 34.000 .000 & 0,01293 \\
Peralatan Transportasi & 322.000 .000 & 0,1225 \\
\hline Total biaya investasi & & 100,00 \\
\hline
\end{tabular}

Sumber : Hasil Olahan Data Primer Tahun 2007

\section{Aspek Teknis Calon Lokasi Tambak Di Desa Dusun Baru Pelokan}

Berdasarkan hasil penelitian, lokasi yang direncanakan untuk dijadikan tambak berada di Desa Dusun Baru Pelokan Kecamatan Muko-Muko Utara Kabupaten MukoMuko Propinsi Bengkulu merupakan wilayah pesisir. Sebagian besar kegiatan budidaya perikanan di wilayah pesisir adalah usaha perikanan budidaya tambak udang, bandeng atau campuran keduanya. (Dahuri, 2004).Luas calon lokasi tambak adalah \pm 500 ha. Jarak lokasi tambak dengan laut $\pm 100 \mathrm{~m}$ dan jarak dengan Muara Sungai Manjunto $\pm 100 \mathrm{~m}$. Vegetasi calon lokasi tambak adalah tanaman sawit usia muda, tua dan sedang. Teknologi yang digunakan untuk membersihan lokasi tambak tersebut. Berdasarkan pengamatan di daerah penelitian, tekstur tanah calon lokasi tambak di Desa Dusun Baru Pelokan Kabupaten Mukomuko adalah sandy (pasir). Di lapangan, tekstur ditentukan dengan memijat tanah dengan jari-jari dan dirasakan kasar halusnya.dalah menggunakan tenaga buldoser rata-rata sewa exavator adalah sebesar Rp 365.000/jam. pembuatan pematang disiasati dengan tanah timbunan seluas $10 \mathrm{Ha}$ dengan asumsi jarak tanah timbunan sejauh $10 \mathrm{~km}$ dari calon lokasi tambak, pengangkutan tanah dan biaya penimbunan tanah 
menggunakan tenaga exavator (sewa) dengan rata-rata biaya $25.000 / \mathrm{m}^{3}$. Hal ini berbeda dengan pembuatan pematang dari jenis tanah merah pada tambak udang Kilau Samudera Pondok Kelapa yang membutuhkan biaya rata-rata $10.000 / \mathrm{m}^{3}$.

\section{Aspek Teknis Calon Lokasi Tambak Di Desa Dusun Baru Pelokan}

Berdasarkan hasil penelitian, lokasi yang direncanakan untuk dijadikan tambak berada di Desa Dusun Baru Pelokan Kecamatan Muko-Muko Utara Kabupaten MukoMuko Propinsi Bengkulu merupakan wilayah pesisir. Sebagian besar kegiatan budidaya perikanan di wilayah pesisir adalah usaha perikanan budidaya tambak udang, bandeng atau campuran keduanya. (Dahuri, 2004).Luas calon lokasi tambak adalah \pm 500 ha. Jarak lokasi tambak dengan laut $\pm 100 \mathrm{~m}$ dan jarak dengan Muara Sungai Manjunto $\pm 100 \mathrm{~m}$. Vegetasi calon lokasi tambak adalah tanaman sawit usia muda, tua dan sedang. Teknologi yang digunakan untuk membersihan lokasi tambak tersebut. Berdasarkan pengamatan di daerah penelitian, tekstur tanah calon lokasi tambak di Desa Dusun Baru Pelokan Kabupaten Mukomuko adalah sandy (pasir). Di lapangan, tekstur ditentukan dengan memijat tanah dengan jari-jari dan dirasakan kasar halusnya.dalah menggunakan tenaga buldoser rata-rata sewa exavator adalah sebesar Rp 365.000/jam. pembuatan pematang disiasati dengan tanah timbunan seluas $10 \mathrm{Ha}$ dengan asumsi jarak tanah timbunan sejauh $10 \mathrm{~km}$ dari calon lokasi tambak, pengangkutan tanah dan biaya penimbunan tanah menggunakan tenaga exavator (sewa) dengan rata-rata biaya $25.000 / \mathrm{m}^{3}$. Hal ini berbeda dengan pembuatan pematang dari jenis tanah merah pada tambak udang Kilau Samudera Pondok Kelapa yang membutuhkan biaya rata-rata $10.000 / \mathrm{m}^{3}$.

\section{Asumsi Penerimaan Usaha Tambak Udang}

Tabel 6. Penerimaan Usaha Tambak Udang 450 Ha di Kabupaten Mukomuko.

\begin{tabular}{|c|c|c|c|c|c|c|}
\hline \multirow{2}{*}{ Size } & \multirow{2}{*}{ Uraian } & \multirow{2}{*}{$\begin{array}{l}\text { Harga } \\
(\mathrm{Rp})\end{array}$} & \multirow{2}{*}{$\begin{array}{l}\text { Produksi } \\
\text { (ton/tahun) }\end{array}$} & \multicolumn{2}{|c|}{ Penerimaan } & \multirow{2}{*}{$\begin{array}{c}\text { Persen } \\
(\%)\end{array}$} \\
\hline & & & & Rp/siklus & Rp/Tahun & \\
\hline 30 & Kualitas Fresh & 68.000 & 360 & 145.920 .000 .00 & 291.840 .000 .00 & 81 \\
\hline
\end{tabular}




\begin{tabular}{|c|c|c|c|c|c|c|}
\hline 50 & & 43.000 & 5520 & & & \\
\hline $\begin{array}{l}58 \\
62\end{array}$ & Kualitas Second & $\begin{array}{l}35.000 \\
33.000\end{array}$ & $\begin{array}{l}736 \\
724\end{array}$ & 34.232 .880 .000 & 68.465 .760 .000 & 19 \\
\hline \multicolumn{4}{|c|}{ Total } & $\begin{array}{r}180.152 .880 .00 \\
0\end{array}$ & $\begin{array}{r}360.305 .760 .00 \\
0\end{array}$ & 100 \\
\hline
\end{tabular}

Sumber : Data Primer Diolah, Tahun 2007

Dari Tabel 6 menunjukkan bahwa penerimaan usaha tambak udang $450 \mathrm{Ha}$ di Kabupaten Mukomuko sebesar Rp 360.305.760.000/tahun. Rata-rata penerimaan per Ha adalah $\mathrm{Rp}$ 800.679.467. Penerimaan tersebut terdiri dari produksi udang kualitas fresh (Sise 30 untuk 50 Petak, size 40 untuk 100 petak, size 50 untuk 1150 petak ) sebesar $81 \%$ dan produksi udang kualitas second (size 58 untuk 200 petak, size 62 untuk 300 petak) sebesar $19 \%$. Penerimaan udang kualitas fresh diasumsikan karena dilakukannya manajemen dan pemeliharaan yang baik, dan asumsi penerimaan kualitas second disebabkan jenis tanah dasar pasir yang bersifat peraeus dan sangat sedikit mengandung makanan alami/alga bagi pertumbuhan udang (Buwono, 1992). Udang dapat dipanen ketika berumur 4 bulan. Pada tahun pertama penerimaan diperoleh sebesar Rp 180.152.880.000 karena di tahun pertama tambak baru dapat berproduksi satu kali. Panen udang adalah 2 kali panen dalam satu tahun.

\section{Sumber Modal (Dasar Perhitungan Pembayaran Pinjaman)}

Berdasarkan analisis investasi, kebutuhan biaya investasi dan modal kerja yang diperlukan untuk rencana pembuatan tambak udang di Kabupaten Mukomuko sebesar Rp 378.659.375.000 . Investasi sebesar ini tidak sepenuhnya dipenuhi dari modal sendiri karena tanpa mengadakan pinjaman dari luar, perusahaan mungkin mengalami kesulitan dalam pengadaan dana, baik untuk biaya investasi maupun modal kerja sehingga pembiayaan pembuatan tambak udang ini harus mendapatkan modal pinjaman dari pihak luar dalam hal ini meminjam dari PT. Bank Rakyat Indonesia berupa kredit investasi jangka panjang. 
Pada analisis kelayakan finansial usaha tambak udang ini, pinjaman Periode I sebesar $30 \%$ dari modal investasi dan modal kerja, sehingga modal pinjaman periode I pada PT. Bank Rakyat Indonesia sebesar Rp 113.597.812.500. Penerimaan pada tahun pertama tidak dapat menutupi biaya modal kerja pada tahun ke 2, sehingga perusahaan melakukan pinjaman periode ke II $20 \%$ sebesar Rp 46.047.120.000. Sehingga total pinjaman seluruhnya sebesar $50 \%$ Modal Sendiri usaha tambak udang ini sebesar $50 \%$. Sumber pinjaman terbagi 2 yaitu $50 \%$ adalah pinjaman dengan dikenakan bunga dari Perbankan (PT. BRI) dan $50 \%$ pinjaman dari Pemerintah Daerah (Pemda). Pinjaman kepada Pemda tanpa dikenakan bunga selama umur proyek. Batas kelayakan pinjaman usaha tambak udang kepada pihak perbankan (PT.BRI) sebesar $\quad 30 \%-50 \%$.

Masa pengembalian pinjaman selama 10 tahun dengan grace period selama 1 tahun. Pada grace period (masa tenggang) hanya dibayar bunga dari total pokok pinjaman, hal ini adalah merupakan kesepakatan dan perjanjian dengan pihak PT. BRI. Artinya perusahaan harus mulai membayar angsurannya pada tahun ke 2 (bunga ditambah dengan pokok pinjaman) setelah proyek tambak udang ini berproduksi

\section{Kelayakan Aspek Finansial}

Hasil penelitian menunjukkan bahwa dari analisis finansial pada tingkat discount rate $15 \%$ diperoleh nilai Gross B/C Ratio sebesar 1,045, nilaii iNet B/C Ratio sebesar 1,346 artinya setiap biaya yang dikeluarkan sebesar Rp 100 akan memberikan penerimaan sebesar Rp 134,6, nilai Profitability Ratio sebesar 1,346, nilai NPV sebesar Rp 91.143.119.070, nilai IRR sebesar 19,93 \% dan nilai Payback Period selama 4 tahun. Sumber pinjaman ke 2 sebesar $50 \%$ berasal dari Pemerintah Daerah tanpa dikenakan bunga selama umur proyek. Artinya bahwa usaha tambak udang di Kabupaten Mukomuko layak untuk dilaksanakan. Berdasarkan hasil Analisis Sensitivitas, menunjukkan bahwa 
jika terjadi penurunan produksi $6 \%$, penurunan harga jual $6 \%$ dan kenaikan biaya input

$11 \%$, maka usaha tambak udang tersebut tidak layak untuk untuk dilaksanakan

\section{KESIMPULAN}

1. Secara sosial, berdasarkan indikator persepsi dan tingkat pengetahuan masyarakat, maka usaha tambak udang di Kabupaten Mukomuko layak untuk dilaksanakan.

2. Secara Finansial, apabila sumber modal diperoleh dari pinjaman kepada pihak perbankan (PT.BRI) sebesar $50 \%$ maka usaha tambak udang di Kabupaten Mukomuko layak untuk dilaksanakan hal ini terlihat dari analisis finansial pada tingkat discount rate $15 \%$ diperoleh nilai Gross B/C Ratio sebesar 1,045, nilai Net B/C Ratio sebesar 1,346, nilai Profitability Ratio sebesar 1,346, nilai NPV sebesar Rp 91.143.119.070, nilai $I R R$ sebesar 19,93\% dan nilai Payback Period selama 4 tahun. Sumber pinjaman ke 2 sebesar $50 \%$ berasal dari Pemerintah Daerah tanpa dikenakan bunga selama umur proyek.

3. Berdasarkan hasil Analisis Sensitivitas, menunjukkan bahwa jika terjadi penurunan produksi $6 \%$, penurunan harga jual $6 \%$ dan kenaikan biaya input $11 \%$, maka usaha tambak udang tersebut tidak layak untuk untuk dilaksanakan.

\section{DAFTAR PUSTAKA}

BEINEWS. 2005. Industri Perikanan Masih Kaya Protein. www.bexi.co.id/images/_res/perbankan_Industri Perikanan

Dahuri. 2005. Prospek Investasi dan Bisnis Di Sektor Kelautan. www.bexi.co.id/images/_res/perbankan_prospek

Gray, C dan Payaman Simanjuntak. 1993. Pengantar Evaluasi Proyek-Proyek. Edisi Kedua Gramedia. Jakarta

Koeshendrajana. 2002. Analisis Sosial Ekonomi Budidaya Udang Galah (Macrobrachium rosenbergi) Di Kabupaten Gianyar Bali. Volume 8 No 7. Jurnal Penelitian Perikanan Indonesia Edisi Sosial Ekonomi. Badan Riset Kelautan dan Perikanan. Departemen Kelautan dan Perikanan 